\title{
Writers in Arms and the Just War: The Spanish Civil War, Literary Activism, and Leftist Masculinity
}

\section{Michele Haapamaki}

Ralph Fox was killed in action against the Spanish rebels and their Fascist allies... We shall honour his memory best, and that of the other fallen comrades, by redoubling our efforts on behalf of the Spanish people. ${ }^{1}$

This Left Review obituary for Ralph Fox, killed at the age of 37 on the Cordova Front in Spain, reflected the close integration between radical politics, revolutionary writers, and identification with the Republican Spanish cause in the 1930s. Support for the fledgling leftist and democratically elected Popular Front government against the Franco Nationalist rebellion was an issue over which an otherwise divided British left could unite. Yet despite the almost uniform support for intervention advocated by leftist intellectuals, to the British government the conflict was merely an anachronistic Latin quarrel in which it was best not to meddle. Participation in the militias became a political statement not only against Fascism, but also against the apathetic stance of Western governments. Approximately 2700 volunteers from Britain defied the official "non-intervention" policy that rendered their participation illegal.

Left-leaning literary journals, novels, and political pamphlets presented the conflict as the Writer's or Poet's War, a struggle in which culture was intimately involved. Stephen Spender, an observer and participant, labelled it as such and later commentators, such as literary historian Margot Heinemann and Frederick R. Benson in Writers in Arms, proved powerful carriers of this romanticized notion. ${ }^{2}$ The Last Great Cause, a work written during the political upheaval of the late 1960 s, is a similarly dramatic title for an event seen in apocalyptic terms by its intellectual participants. ${ }^{3}$ The fact that Spain was hardly a "Poet's War," and that at least 80 percent of British volunteers were working class, does not diminish the Spanish Civil War as an event of primary importance to leftist intellectuals seeking to legitimate their political credibility. The builders of this entrenched myth, many of whom, like Heinemann, were deeply committed to the cause, have constructed the narrative of the Just War, which has served as a rich field for recent historians to explore issues of leftist politics, culture, masculinity, and heroism.

This article considers the close-knit community around the Communist writers and intellectuals of the Writers' International and Left Review from 1934-1938, and how their participation in political and armed opposition to 
Spanish Fascism was portrayed. It is a necessarily selective account, providing a representative sampling of both written accounts of Spain and eulogies to fallen martyrs of the cause. These are culled from Left Review itself, memorial pamphlets, books, and other leftist journals of the 1930s. In particular, I will emphasize how the construction of the leftist heroic soldier was fraught with contradictions, and how national identity and traditional military and masculine qualities functioned in this space. A focus on mentalities towards war and the heroic portrayal of the armed intellectual illuminates how leftist intellectuals justified a form of soldiering consistent with their ideological beliefs and from which a heroic myth emerged to sustain and commemorate the cause.

Historians have tended to focus on several areas of leftist participation in the Spanish war, many of which contain intertwined themes of politics, gender, and ideology. On the political front they have focused on the role of the International Brigades and the failure of the British left to make a broad-based impact with the campaign to aid Spain. ${ }^{4}$ Recent historians are acutely aware of the hagiography that the Spanish War has acquired and seek to deconstruct the leftist metanarrative of the Just Cause. James K. Hopkins, in Into the Heart of the Fire, points to the remarkable resiliency of the mythology of the Spanish cause and the badly flawed representations of the "Volunteers for Liberty," not least of which was the notion of the Poet's War. He argues that the mythology of the Civil War was a middle-class construction, one that relegated its worker participants to cliché and stereotype. ${ }^{5}$ Robert Stradling in History and Legend uses the question of masculinity and the definition of the heroic to pose additional questions about the myths of Spain. ${ }^{6}$ Other important contributors to the literary history of Spain include Andy Croft and David Margolies, the latter of which argues that Left Review cannot be viewed merely as an organ of Communist Party propaganda.?

With a view to the representational pitfalls of the dominant intellectual narrative of Spain, and of uncritically accepting the middle-class bias and mythology of the Just Cause, this article takes into consideration several aspects of the contemporary leftist literary depiction of Spain. Firstly, the legacy of the Great War on leftist attitudes towards war must be explored in order to contrast the representation of the "betrayal" of 1914 with the Just Cause of Spain. Entailed in this was the embrace of a certain leftist form of militia soldiering, as well as the persistence of traditional motifs of sacrifice and quasi-religious symbolism. Few studies have explored the particular representation of "Britishness" displayed in leftist writing on Spain. This article will emphasize the link between masculinity and the identity of the warriors as British heroes. In conclusion, I will argue that the experience of Spain ultimately succeeded in pulling the majority of the British leftist constituency away from the pacifist and internationalist ideology that had been the legacy of the Great War, and into the fold of the British national mainstream in preparation for the Second World War. 
Issues of the Popular Front and the construction of the artist as revolutionary soldier played out in the contemporary print culture of the radical left, such as the literary community of the London-based Left Review, the official journal of the Communist Writers' International. Launched with a starting capital of $£ 27$, the journal was first published from Collet's Bookshop on Charing Cross Road. ${ }^{8}$ This location served as an appropriate stage for the tightly woven community of mainly Communist writers, journalists, and editors who saw their position as that of the radical literati. Left Review began under the editorship of Montagu Slater, a post that later passed to Randall Swingler, Edgell Rickwood, and then Tom Wintringham. Offering readers a mixture of poetry, literature, reportage, and reviews of books, films, music, and theatre, the journal incorporated a realist style and a Marxist literary critique. ${ }^{9}$ The impression of Left Review was of a lofty experiment, reflected in Montagu Slater's pronouncement that the journal "comes at a time of intellectual avidity ... it comes, like a Shakespeare play, in the midst of a crowd of inferiors." "touchstone" of contemporary leftist opinion, where well-known British writers including Naomi Mitchison, W. H. Auden, Stephen Spender, Charles Madge, Anthony Blunt, Jack Lindsay, Nancy Cunard, Rex Warner, and C. Day Lewis shared print with colonial and continental writers such as Mulk Raj Arnot, Bertold Brecht, and André Malraux. Although the editorial board of Left Review, as well as the leadership of the Writers' International, was solidly Communist, contributors to the magazine also featured non-Communists such as George Orwell and John Lehmann.

Within the community of the Writers' International, the deaths in action of writers and intellectuals such as Ralph Fox, Christopher Caudwell, and John Cornford recast the concept of the Just War and helped to recreate an acceptable leftist warrior hero, a particularly British warrior hero, for the reality of imminent war. The representation of sacrifice provides a dynamic narrative of how identification with, and participation in, anti-Fascist war brought to the pacifist left what it would have least desired or anticipated - soldier heroes, and an uneasy acceptance of their own participation in armed conflict. Seeking to redeem lost ideals of the Great War, the militia fighter was fashioned as an independent agent in the revolutionary cause. A growing intellectual acceptance of the notion of a Just War, conflicted as it was, facilitated a renewed sense of national identity, and a coherent sense of Britishness, which included the heroism of the individual.

The 1930s, with its immediate concerns over domestic and international crises, was a crucial moment in the production of leftist journalism and literature. For Communist Party members in particular, the decade occasioned feelings of persecution from all sides, not only from capitalist culture, but also from 
mainstream Labour, whom they perceived as having allied with the capitalist establishment to thwart a real alteration of the economic order. The 1930 s witnessed an attempt to revitalize the revolutionary Left, but it again resulted in fragmented politics, with Labour committed to gradualism. From 1928 to 1935 the Communist Party of Great Britain campaigned under a "class against class" policy adopted from the Sixth World Congress, with direct opposition to the "sham left wing." This position has been interpreted as a policy disaster after which relations between the Communists and the Labour Party would never recover." Although the Seventh World Congress of the Communist International in 1935 advocated a united front against Fascism, Labour had already expelled Communists from its ranks. In the December 1936 issue of Left Review, Harry Pollitt, the Communist Party secretary, called on workers to support the People's Front. ${ }^{12}$ The Popular Front, as it became known, would then become the focus of the Writers' International, mixed with a strong dose of the "cult of Russia." Stradling argues that many of the intellectuals who would participate in Spain, not only Orwell, held extreme reservations about the conduct of the Soviet Union and the Communist Party, but their "defection" only came afterwards, when they would be immune from charges of Trotskyism or being "Fifth Columnists" during the conflict itself. ${ }^{13}$

These particular circumstances produced several effects on leftist cultural production, one of which was that Communist and socialist writers enjoyed the advantage of a burgeoning community of small publications that were often produced by an overlapping group of writers and editors. Individuals such as Slater, Lehmann, Fox, Madge, George Lansbury, and Margaret Cole appeared on many leftist publication mastheads. Journals of literature and criticism such as Left Review, Fact, New Writing, Time and Tide, and The Left Book News ensured that the poets and writers of Spain enjoyed an expanded audience for their work. It is important to contextualize British Spanish Civil War writing within the wider circle of participants in the greatest war propaganda effort that had ever been mounted by writers, artists, photographers, and filmmakers. As such, Left Review is an example of the trend towards socialist realism, in appearance simulating the stark modernist style favoured by Soviet propaganda, while at the same time attempting to forge a British Marxist critical tradition, exemplified by the writings of Caudwell.

These networks contributed to leftist intellectual legitimacy in the 1930s. For example the Left Book Club, published by the prominent Labour organizer Victor Gollancz and with its total of 60000 members at the height of its prominence, proved that leftist intellectual discussion could garner a large and engaged audience. The advent of both the mass and the modern challenged the left to both adapt to artistic modernity and continue the inheritance of a lively radical print tradition. The labour newspaper Daily Herald edited by Lansbury, the New Statesman founded by Fabians Sidney and Beatrice Webb in 1913, the 
inauguration of the Communist Party's Daily Worker in 1930, and the weekly Tribune that included Gollancz, Stafford Cripps, Aneurin Bevan, and Harold Laski on its editorial board, represented a range of leftist media that sought to create a political discourse between the public and the intelligentsia.

\section{II}

For many leftist intellectuals, Spain was intimately connected to memory of the Great War and reflected the elements of both revulsion and fascination that it provoked. Some, such as Spender, viewed Spain as an opportunity for redemption in which a post-war pacifist generation might exonerate its guilt at having missed the Great War. He acknowledged this burden of guilt in his essay The God That Failed, and wrote in his autobiography World Within World that the intellectuals who went to Spain were divided between "their artistic and their public conscience, and unable to fuse the two."14 Two intellectuals who survived battle, Wintringham and Humphrey Slater, were trained soldiers, a fact that Spender assumed to indicate that the role of the others was simply to become martyrs. ${ }^{15}$

Many historians have considered the influence of the Great War on leftist pacifism of the interwar years, and regard it as one of the contributing factors in the tenuous relationship between the left and patriotic identity. Some socialists opposed the war in 1914 believing their position to be more patriotic by protesting an un-English war. In doing so, these socialists drew on the tradition of "oppositional Englishness," based on a radical notion of representing the freeborn Englishman against elite tyranny and aristocratic corruption. ${ }^{16}$ However, opposition to war in 1914 proved an unviable position for the Labour party, and many intellectuals in the post-war period would be haunted by this failure of will to oppose a war they felt to be deeply unjust. The issues of the 1930 s, as Samuel Hynes writes in $A$ War Imagined, were defined by the remembering of the war, and the subsequent Myth that was to be constructed as the "truth" about the conflict. By 1930, the Myth was firmly established - horror at the destructiveness of modern war, a loss of faith in civil institutions, incomprehension, and pessimism about the direction of civilization. ${ }^{17}$

As Hynes identifies, a sense of leftist culpability was also a legacy of the war - not only the fact that socialists had acquiesced to the state, but that many had done so enthusiastically. Roland Stromberg in his work on intellectual excitement at the advent of the war, explains this as a manifestation of the "yearning for community," a feeling to which Germans were supposedly particularly predisposed, but which equally prompted British intellectuals to nationalistic fervor. ${ }^{18}$ Consequently in the post-war period Hynes identifies a "spirit of urgent, anxious pacifism - the spirit that in the Thirties would produce the Peace Ballot and the Peace Pledge Union."'19 Pacifism was probably the most 
enduring ideology resulting from the Myth of the Great War. Martin Ceadel makes a distinction between pacifism and pacificism - the former was the belief that war was always morally wrong, and the latter a principle that war was inhumane, and that all attempts should be made to prevent war if possible. ${ }^{20}$ It was the latter position that most leftist critics maintained during the 1930s, and one that they were prepared to abandon when it became clear that Fascism would only be halted by war. Attitudes towards war and tenuous murmuring about pacifism, therefore, were contingent on the nature of the cause, and hence the first item of business for the Spanish war chroniclers would be to construct the cause itself as heroic. The advent of heroes, lauded for bravery, commitment, loyalty or courage, was a by-product of propagating and memorializing the cause.

The legacy of the Great War contributed powerfully to the discussion of future war. For example, the introductory issue of the Writers' International journal featured a discussion entitled "Writers and War," in which literary figures submitted pieces "to express their opposition to the warlike plans of the imperialist governments." George Bernard Shaw expressed a fear of rearmament, and Madge charged bourgeois intellectuals with complicity in the First World War in the editorial "Pens Dipped in Poison":

In 1914, when the shadow of war fell on the bourgeois intellectuals, they were taken completely unawares, and accepted quite uncritically the doctrines of a 'righteous war' offered them ... those who had a vague, idealist, liberal ideology committed the greatest excuses and lost their head most completely when war broke out.... It is therefore all the more necessary that writers and intellectuals of the present have the clearest ideas on the subject of war, its causes and the possble means of preventing it. $^{21}$

Contemporary commentators who had portrayed the European conflict as a "holy war" that would cleanse and restore imperial and national vigour were similarly lambasted, such as Poet Laureate Robert Bridges who had stated in 1914 that, "I hope that our people will see that it is primarily a holy war." Nor were leftist leaders of 1914-1918 spared criticism. Left Review, in commending First World War conscientious objectors such as Lowes Dickinson and Bertrand Russell, criticized the Independent Labour Party and the Socialist Review for their pro-war stance during the conflict. ${ }^{22}$ A November 1934 article by "Ajax" concentrated on mobilizing writers for the "war against war," and condemned the military tradition. In a review entitled "Heroism? Adventure? Glory?" three war memoirs were scathingly portrayed as attempts to infuse militarism with a moral basis. The reviewer, condemning the creation of heroic figures from the Great War declared, "Heroism, adventure, glory - how tired these words look. They have made some progress during their long convales- 
cence after breakdown through overwork in 1918, yet they still seem very thin."23 The labelling of war itself as primarily "Fascist" or "capitalist" was used as a basis for defining Marxist pacifism. A review of the pacifist book The Citizen Faces War in 1936, emphasized "It is not Marxist to believe that war is inevitable." Capitalism, imperialism, and elites were held responsible for war and the thwarting of class revolution. ${ }^{24}$ Heroism was seen as a form of false consciousness, diverting working-class participants from the revolutionary cause into the service of capitalism.

The path from these resoundingly pacifist editorials in the early Left Review, to the glorification of the intellectual warrior, necessitated a re-orientation of war along leftist lines to counter the anti-heroic legacy of the Great War. The most striking feature of the hagiography surrounding the Spanish War was the glorification of the individual fighter. Although abstract concepts such as liberty, democracy, freedom, and culture were the stated aims of intervention, much commemoration of the war praised the individual solider. As James Hopkins points out, many later felt that Spain provided the last opportunity for the principled individual to alter history. ${ }^{25}$ The portrayal of fighters in the Spanish Civil War involved both a physical and ideological alteration of the concept of soldiering. Drawing the dichotomies of the militia and irregular solider, as opposed to the regular soldier of the nation state, may help explain the symbolic importance of Spain to the notion of the citizen soldier, a notion that would powerfully affect the British experience in the Second World War.

The March 1937 cover of Left Review featured the sketch of a highly masculine, muscle-bound, and potent militiaman. His powerful upper body, clearly drawn out of proportion, signalled a strong military masculinity, but one constructed outside of the confines of the nation state. ${ }^{26}$ It was reflective both of Soviet propaganda films and posters, and of the idealized proletariat male, and the civilian clothing of the individual solider was particularly important in this imagery. The absence of uniform denoted an absence of hierarchy and authoritarianism, and signalled equality among fighters. Described by Orwell, the self-styled uniform, dubbed the "multiform," lessened the impact of rank. The insistence on social equality, such as a Spanish officer who berated a recruit for calling him "Señor," did lend itself to socialist ideology, if not military efficiency or discipline. ${ }^{27}$ By way of contrast, a Left Review cartoon depicted a working-class recruit being marched off by a bulky sergeant. Satirically entitled "The Path to Glory," the piece neatly illustrated the resentment directed towards the military, resentment that lingered from abuses and ineptitude during the Great War. The power of the uniform to inspire fear, obedience, authority, and hierarchy were clear in the juxtaposition of the swaggering sergeant dwarfing, both literally and symbolically, the recruit in civilian clothes. ${ }^{28}$ The image of the militia, then, became a means for the left to accept a warrior role in Spain without simultaneously accepting the baggage of an outdated military ideal dis- 
credited, in their minds, by the Great War.

\section{III}

In the age of pamphlet propaganda, a substantial public relations coup was achieved by the left with the publishing of Authors Take Sides on the Spanish War in 1937. Initiated by Nancy Cunard and published under the unofficial auspices of Left Review and featuring a survey of prominent British writers, the project was clearly intended as a propaganda coup for intervention; its results came down firmly on the side of the Republican cause. The phrasing of the main question was highly leading: "Are you for or against the Legal Government and the people of Republican Spain? Are you for or against Franco and Fascism? For it is impossible any longer to take no side." Given such phrasing, it is highly unlikely that any author would want to publicly identify against "Legal Government" and for "Fascism." The published results, 127 writers "FOR the Government," five "AGAINST the Government," and seventeen classified as neutral, were taken as almost unequivocal intellectual support for intervention. In addition, questions about both the classification of some responses and the number of right-leaning writers who were ignored, suggest the doubtful legitimacy of the project. ${ }^{29}$ However, the fact that so few writers were willing to go on record as "neutral" is instructive, if only because it points towards the intellectual pressure of Popular Front sentiment.

The question of neutrality also developed into an intellectual spat related to Left Review's coverage of the Spanish question. The neutrality of T. S. Eliot, editor of Criterion, was a challenge to the absolutism of the Authors Take Sides creators - an annoyingly detached attitude to proponents of action. Writing in Criterion, he dismissed the creators of Taking Sides on the Spanish Civil War as "irresponsible zealots. ${ }^{\text {" }} 30$ Eliot's response to the survey, that "at least a few men of letters should remain isolated," and refusal to be drawn into the ideology of manifestos, was anathema to the ascendant intellectual activism of Left Review.

In 1936, C. Day Lewis opined in Left Review that writers must act, "throwing off [their] parochialism and political apathy in the interest of the civilization we have helped to build and can help to save," ${ }^{\text {'3l }}$ quickly followed by his editorial "Sword and Pen." 32 He argued that in Spain "the defence of culture is a reality and is achieved with arms in hand ... behind the lines we are also at the front." Because the artist "lives his life more intensely and vitally," he was also responsible for defending cultural freedom. ${ }^{33}$

One of the major interventions that the Writers' International (the British and European sections) was to hold was a Writers' Congress in Madrid in 1937 when the city was in the midst of being shelled. Spender wrote rather positively about the Congress for an autumn 1937 issue of New Writing. ${ }^{34}$ Reflecting more bitter feelings, he would later write that the people of Spain seemed to 
have a "touching faith" that the appearance of los intellectuales would bolster their cause, and decided that the whole exercise, for its good intentions, had the qualities of a "Spoiled Children's Party." ${ }^{35}$ Left Review, unsurprisingly, accorded the proceedings rather more gravitas, with a two-part report compiled by Edgell Rickword that formed part of its "Spanish Number" in September 1937.

A sampling of material published in Left Review relating to Spain included pieces such as Ralph Bates' "Companero Sagasta Burns a Church" which Bates personally witnessed, himself deciding which relics to preserve and which to destroy. ${ }^{36}$ Sylvia Townsend Warner blamed Anarchists, not Communists, for anti-clerical violence, and Rickword and Lewis emphasized the centrality of Spain to civilized culture with the customary "defence of culture" argument. Rickword ridiculed the official policy of non-intervention with his poem "To the Wife of Any Non-Intervention Statesman." ${ }^{37}$ Poems were also contributed by John Cornford and Tom Wintringham, and the publication included stirring mass declamation pieces such as Jack Lindsay's poem "On Guard for Spain." The poem advocated violent resistance to Fascism: "Tear down the oppressors.... Smash with our bare hands the iron door of greed." The workers of the world were urged to form their own "compact of steel," to save the "human future" itself. . $^{38}$

The inclusion of poetry memorializing Spain in Left Review occurred under the editorship of Rickwood, a soldier and anti-war poet of the Great War, a war in which he had lost an eye. Although Rickwood's own war poetry had been marginalized by the literary world in favour of Siegfried Sassoon, Wilfred Owen, and Rupert Brooke, he published some of the most memorable lines of Spanish Civil War verse. The martyred Spanish poet Federico García Lorca, brutally killed by Nationalist forces, proved that even the most severe antiFranco propaganda had, in fact, been correct; his death served as a marker of the barbarianism of the Fascists. Much of the poetry of the Spanish Civil War was clearly propagandist in intent. Auden's "Spain" was perhaps the most memorable mobilization poem to come out of the Spanish War, and was sold as a fundraising pamphlet. The Gollancz publication The Left Book News (later The Left News) featured reports from Spain by Clement Attlee and Gollancz's own strident calls for intervention. Even the usually non-political, though leftleaning New Writing, edited by John Lehmann, featured a Spanish Number in the spring of 1937, containing political pieces on Spain, including translations from Spanish and John Sommerfield's "To Madrid."

Varying groups of writers contributed to the mythology of Spain, with differing impact and legacy. What came to be known as the "Auden group" were poets led by Auden and including Spender and Lewis. The labelling, however, was more a construct of middle-class myth than reality since its members cannot be said to have held a single cohesive ideology either during or following Spain. In addition, there were the reportage and war narrative writers, such as 
Lehmann, John Sommerfield, Ralph Bates, Cyril Connelly, T. C. Worsley, Orwell, and Wingtringham, not all of whom actually fought in Spain, but who wrote accounts of the conflict. Many poets and writers who wrote about the Civil War from the safety of England felt a particular guilt regarding their nonparticipation, such as Lewis who admitted that he felt that he should have joined the International Brigade, but lacked the conviction to follow through. The third group constitutes the "martyrs," writers later raised to the pantheon of civil war participants by myth and commemoration, and who need to be considered in a separate category for the representations of their death in Spain.

The first British volunteer to be killed in Spain was a woman, Felicia Browne, an artist from a privileged background who had contributed sketches to Left Review. Killed in August 1936 while taking part in an attempt to blow up a rail station, Browne has remained a little known participant, although her gender did provoke some effusive eulogies at the time of her death. The exact manner of her death remains unclear. Most accounts placed her running through a firefight to aid a wounded comrade. ${ }^{39}$ Browne's decision to head out on a sabotage party with the self-styled "Storm Troops" despite her limited military training was typical of the heady feeling that Spain would provoke. Left Review's final editorial in 1938 listed several of its writers who had fought in Spain: Ralph Fox, John Cornford, Charles Donnelly, Sommerfield, Wintringham, and Bates, the first three of whom were to die on the front. ${ }^{40}$ In addition, W. Rowney (the cartoonist "Maro") and Julian Bell were also among the dead of the British Brigades. ${ }^{41}$ Eulogizing the fallen in 1937, Rickword declared, "These men have re-established with their blood that unity between the creators of beauty and the masses of the people."

The fusion of intellect and martial bravery featured in every eulogy and, arguably, the almost religious language employed to memorialize the dead reflected traditional military discourses of struggle and sacrifice. Some historians such as Hynes in $A$ War Imagined and Modris Eksteins in Rites of Spring ${ }^{43}$ have suggested that the Great War occasioned a break with "tradition" and the beginning of "modern" artistic representation and commemoration. They argue that, in reference to war in particular, traditional motifs of sacrifice and service no longer resonated in the post-war period. Other historians such as Jay Winter, however, have argued to the contrary that traditional and religious ways of commemoration, grief, community, and religious representation endured. ${ }^{44}$ Winter emphasizes continuity and the "persistence of tradition" as the defining ethos of the language of mourning and remembrance practiced in all participant countries after the war. The discourse of sacrifice as represented in the visual, verbal, and social languages of mourning held more to nineteenth century forms than to modernist abstraction, which could only express emotion rather than help to heal it. As will be demonstrated, the quasi-religious language of sacrifice formed the basis of the eulogies of the Spanish fighters from the left. 
Slater's eulogy for Donnelly, a member of the Irish Company of the American Lincoln Brigade, brought together the warrior with the man of letters. A contributor to Left Review, Donnelly has been likened to "the Irish equivalent of England's John Cornford - the Byronic martyr at once unique and utterly characteristic of his type." ${ }^{.45}$ Montagu commended Donnelly for bravery in that "all the letters from Spain speak of his gallantry in the fighting." Active risktaking on the front was depicted as fusing Donnelley's intellect and spirit, leading to the writing of powerful verse in extraordinary circumstances: "For Donnelly public and private living had come together and were to be fused in dying." ${ }^{46}$ Jack Lindsay wrote the poem "Requiem Mass: For the Englishmen fallen in the International Brigade" that mentioned particular fighters by stan$\mathrm{za}$, both intellectuals and worker participants. The religious imagery reflected the status of the Spanish Republic and the Popular Front as a secularized religion of its proponents.

The primary figures of the Communist Party who became objects of martyrdom were Fox, Caudwell, and Cornford. Fox was a journalist, literary critic, and political activist who joined the Communists in 1925 and devoted his talent to Communist organization. A writer with wide-ranging interests, he published works from biographies of Lenin and Genghis Khan to treatises on political economy and literary reviews. Having served as a teenager in the closing stages of the Great War, he had returned from the experience "with a lasting sense of kinship with toiling men and a hatred of the war-makers of worldcapital," ${ }^{\prime 47}$ perhaps making the call of the Just War some two decades later all the more powerful. Published as a posthumous tribute to his best writing, the volume Ralph Fox: A Writer in Arms included a range of his essays. The introductory pieces focused on Fox as a fighter, with each developing a separate aspect of Fox's heroism. Communist Party official Harry Pollitt praised Fox's "deep sense of intellectual conviction," and Michael Gold urged other writers to "Take your place in the ranks! Organize! Educate! Fight! Freedom needs every soldier, and books are not enough!" 48

Taken together, these accounts summarized much of the construction of the intellectual warrior hero, a heroism doubly secured in violent death. Fox's comrades who described his "shouting from sheer joy in battle" ${ }^{\text {"49 }}$ were defining the essence of the Just War. The official account of Fox's death was of him advancing to contact across low ground covered by enemy machine-gun fire, "a supremely brave thing to do." The military commander that Fox served under, noted "I am not just paying a conventional tribute to a dead man when I say that he was a real hero." Emphasizing Fox's British identity and the heroism of the entire British Section, Communist Party official Harry Pollitt noted that General Kleiber of the International Brigade felt that the positions Fox and his British Section comrades helped defend "will be held to the very last." ${ }^{50}$ The association of the left with martial courage and national pride emerged, bring- 
ing leftists closer to the nationalist mainstream.

Lawrence of Arabia, who served as a model for the "irregular" fighter, also served as an example of heroic masculine fantasy that would prove an important element in the Spanish narrative. In a 1935 tribute to Lawrence of Arabia by Fox, significantly entitled "Lawrence the Twentieth Century Hero," the role of the war hero received guarded, contingent endorsement. Fox viewed Lawrence as an anti-capitalist and anti-elitist iconoclast who was at odds with his own class: "He is the only hero whom the English ruling classes have produced in our time, a hero who in his own lifetime gathered about him all the legendary atmosphere of the hero." "sl What Fox implied by liberal use of the term "hero" was that Lawrence's existence within sanctioned military culture was subsumed to higher and nobler ideals. As such, RAF recruiters were subject to satiric criticism by Left Review for using Lawrence's legend to establishment-endorsing ends. ${ }^{52}$ Fox's own death in Spain, ironically, would similarly be used to venerate a cause. The notion that one could be a patriotic Englishman without collaborating with the establishment would prove important to the left and nationalism. Charles Donnelly, a poet and eventually a member of Left Review's "role of honour," also used Lawrence as a model of a writer hero who retained a sense of independence and nonconformity.

Christopher Caudwell, who was killed in his first day of action on the Jarama four weeks after the death of Fox, also became an ardent Communist in the mid 1930s. Having previously written a range of fiction (best defined as "pot-boilers"), poetry, and books on aeronautics, his most important Marxist cultural and scientific studies, including his crowning work Illusion and Reality, were published following his death. ${ }^{53}$ Left Review eulogized Caudwell as a "young writer of great promise" ${ }^{\text {" } 54}$ and the heroic manner of his death heightened interest in his highly theoretical works, works which otherwise might have remained obscure. Caudwell enlisted into the Brigades believing his involvement to be a question of duty, and the fact that if freedom were to fail in Spain, "their struggle ... will certainly be ours tomorrow. ${ }^{55}$

John Cornford, a poet and Communist activist since the age of fifteen, was only twenty-one at the time of his death and served as a legendary figure of tragic embryonic genius. Significantly, fellow poet Louis MacNeice once noted that Cornford was the first inspiring Communist he had ever met. The most famous of his Spanish War poems, "Full Moon at Tierz: Before the Storming of Huesca," resonated with imagery of worthwhile sacrifice and the forwarding of Communism. Cornford's interpretation that "freedom was never held without a fight" affirmed the role of Popular Front fighters and due to its positive bravado has often been used as an example of a "typical" Spanish war poem. Yet, Cornford's only poem to be published in Left Review during his lifetime, "Letter from Aragon," was largely anti-heroic and reflected the mental scars that war inflicted on many participants. It invoked the imagery of coffins, the 
shelling of villages, and militiamen dying agonizing deaths. The poem ended with a warning of Fascist rule of Barcelona, which would turn the city into a "heap of ruins with us workers beneath it." Similarly, many of his letters to Margot Heinemann reflect a measure of ambivalence about the Spanish cause. Various letters range, perhaps understandably, from depression and pessimism regarding the fate of the Republican cause, to the expressed feeling that "having joined, I am in whether I like it or not. And I like it." 57

\section{IV}

It is clear from the historiography that the role of class in the intellectual accounts of Spain has been deconstructed to a large degree, yet little has been said about Britishness and national identity. Necessary to the depiction of the hero in Spain was a changing notion of masculinity, British masculinity in particular, and the sense of the "foreign" that Spain engendered. While members of the left accustomed themselves to supporting the war, heroes emerged that both diverged from, and reflected, imperial and traditional military constructions of masculinity. Leftist accounts of Spain emphasized their characteristics of masculine adventure and fantasy. The leftist "picture of war was as falsely romantic, in its different way, as anything which had stirred the minds of Edwardian boys brought up on Henty and the heroics of minor imperial campaigns" according to participant Philip Toynbee. ${ }^{58}$ The Spanish War provided a contrast between the "stoic and dependable" British volunteer and an image of Latin military ineptitude. Frederick Benson maintained that intellectual fascination with Spain stemmed, not so much from "any exalted belief in the importance of the war for the future of mankind, but rather [from] the realization that something was lacking in their own culture." 59

The narrative of "blood and soil" was essential to the depiction of violence, nation, and self-identity in Spain. One such example is John Sommerfield's "Spanish Diary," a vividly written personal reportage of the International Column, with which Sommerfield saw action. At one point, assumed dead on the front, he returned to Britain in late 1936 to find his obituary being circulated. His writings exemplify what has been called the "rhetoric of violence" and "rhetoric of travel," the Going-into-History that intellectuals imagined. Geography and the crossing of the foreign frontier was a common theme in Spanish Front literature. Reminiscent of the Great War's obsession with boundaries, frontiers, and the front, accounts of Spain and military identity within the Brigades were bound with the notion of the foreign..$^{60}$ In "Spanish Diary" Spanish peasant culture was essentialized as "those voices ringing with vitality, [they] communicated to us something more than enthusiasm, something really distilled from their blood and soil." A tour de force of Latin typology, Sommerfield's pertinent observations included singing and banner-carrying 
peasants, a band playing "a cheerful tang lilt," and railway stations described as "sultry and vegetable." The breathless depiction of arrival in Spain as "something dreamlike, something utterly fantastic," spoke to the fantasy of the travelling hero. ${ }^{61}$

Despite the intertwining of blood, death, and heroism, Left Review was careful to downplay the depiction of Spain as a site of Anglo-Saxon adventure:

The death of Ralph Fox as well as of the other young Englishmen with him can only be understood if it is made entirely clear that this was not an adventure, not the result of quixotic temper, nor spleen, nor rashness, but that these men valued what they gave freely. ${ }^{62}$

Spain, then, despite its interpretation through the lens of the exotic and the foreign, was not an event of soldiers adventuring for rash revolutionaries but a serious political activity, invoking the militia hero. The personal writings of authors such as Sommerfield and Bates (author of The Olive Field) on the other hand support the image of British volunteers engaged in an intense, and intensely foreign, experience. Not unlike earlier colonial narratives, the experience was only heightened by war, physical danger, and cataclysmic political upheaval.

Indeed, the intervention of the left in Spain can be viewed as a subtle mirroring of the British imperial narrative. This is not to suggest that colonialism and anti-Fascist conflict were similar, but to explore how each appropriated notions of a positive, and just, mission. Imperial heroes, Major-General Sir Henry Havelock of the Indian Mutiny or General Charles Gordon at the siege of Khartoum, are examples of the construction of courageous figures of traditional nationalist narrative. The notion of the stalwart British colonialist resisting the primitive "other," conveniently corresponded to imposing cultural ideals and traditions on colonized nations. ${ }^{63}$ Volunteers in Spain, however, claimed an alternate link with the icons of their collective socialist past, while simultaneously employing the heroic imagery of the imperial myth. The 1939 British Battalion commemorative pamphlet illustrated the bridging of Spain, the socialist tradition, and British manhood. Death in Jarama was linked with the British socialist tradition, and the introductory pages portrayed images of British cities and countryside and the working class and intellectuals united without class distinctions. This narrative of classless Spain was, as Hopkins or Stradling might point out, a product of the communist intellectual mythology of cross-class volunteer heroes.

The text stated that, "Out of the Proud traditions of Britain's past they came. Part of the long struggle for freedom ... ready to give their lives that freedom might live." ${ }^{64}$ The "traditions" that were memorialized referred to radical heroes and events such as Byron, the Chartist struggle, and Keir Hardie. Contributors praised the "magnificent heroism of the British Battalion," the 
members of which "typified the real Briton's hatred of the tyrant." The epilogue predicted wider conflict and castigated the government for allowing Fascist aggression, relating the experience of Spain to the future of British democracy. The failed Popular Front conflict was viewed as a training ground for revolutionaries, but more importantly, the pledge to defend Britain more resolutely than Spain had been defended was strongly expressed. The statement that "our fight for world-peace is carried on now under the flag not of Spanish but British democracy" ${ }^{15}$ brought the Spanish experience back to the more familiar territory of home. If the 1930s had represented Going-into-History, the end of the decade brought a returning of the conflict narrative to Britain.

\section{$\mathbf{V}$}

By Left Review's demise in early 1938, after the horrors of the bombing of Guernica and Hitler's intimidation of Czechoslovakia, leftist debate had shifted away from "war against war" towards the question of how best to counter Fascism. The specific circumstances of the 1930s have led to debate regarding the extent to which the British left "rediscovered" the language of nation and oppositional patriotism in the late 1930s. The later portion of the decade, according to Miles Taylor, made it imperative to rehabilitate a positive image of nation and mass politics, and to "rationalize" the masses. These tactics were rendered all the more necessary to both prepare the public to resist domestic fascism in the form of Oswald Mosley's British Union of Fascists, and to prepare for a European war. ${ }^{66}$ The immediate threat of continental fascism occasioned a rediscovering of British peculiarity, and a reversion to traditional motifs of nationalism. Re-invoking notions of the liberal radical past, such as employing the rhetoric of "the people," was part of the attempt to regain a lost rhetoric of radical patriotism.

Orwell's phrase "My country Right or Left" was a sentiment that clearly found resonance. Orwell and J. B. Priestley were among the most important articulators of positive Britishness, transforming "the people" - parochial, boorish and uneducated - into the grand mass of The People - suitable subjects for the People's War. Stephen Lutman interprets Orwell's Homage to Catalonia and The Lion and the Unicorn as establishing a narrative of national allegiance through foreign adventure. Although not an uncomplicated path from lauding the Latin militiamen in Spain, to celebrating the virtues of simple, "ordinary" English people, Orwell spoke to an essentialist nationalist feeling of action and emotion. ${ }^{67}$ Orwell went to Spain with the ILP, setting foot in the country full of political idealism for the Popular Front. He found himself, however, fleeing not from the fascists, but fellow Republicans who crushed the POUM (an independent Marxist militia) in May 1937, on Moscow's orders. His book Homage to Catalonia, which was poorly received at the time it was 
published, reflects the disillusionment that many felt with the turn of political events in Spain, and the role of the Soviet Union in dictating orthodoxy. Certainly Orwell's own turbulent involvement in Spain may have contributed to his embrace of nation and comfortable and familiar British ideals. Likewise, other writers such as Auden, Spender and Christopher Isherwood regretted, in hindsight, their involvement with the far left. Hopkins in Into the Heart of the Fire points to the centrality of the role of the Communist Party in Spain, and its "betrayal" of the volunteers, particularly the working-class volunteers. ${ }^{68}$

The fallout over the official policy of the CPGB from the signing of the Nazi-Soviet pact in August 1939 until the invasion of the Soviet Union by Hitler in 1941 also tempered the claim of a wholesale leftist support of nation and war. Many such as Left Book Club publisher Victor Gollancz, a staunch anti-Fascist in the 1930s who would continue to publish a solidly patriotic "Victory books" series throughout the war, felt betrayed by the policy. The farcical about-face on the Popular Front against Fascism occasioned by Communist policy served only to confirm to moderate Labour that Communists were an unstable and unpredictable element. This policy would continue to divide the far left from mainstream Labour until the invasion of Russia allowed a sudden re-adoption of anti-Fascist rhetoric. Ironically, for many leftists, the German invasion of the Soviet Union relieved an uncomfortable situation in which many had attempted to simultaneously avoid committing themselves fully towards supporting the anti-war policy and remain in the favour of the party.

The Spanish Civil War, a source for political and intellectual stimulation, was also a search for unity and coherence. For the most part, then, the preconditions had been laid for leftist support of the nation at war in 1939. Many contributors to Left Review supported the war effort, such as the Fabian Margaret Cole, the sister of WWI conscientious objector Raymond Postgate. An editor of Fact, a small journal that appeared from 1937 to 1939, Cole prominently supported the Second World War effort. Yet some leftist intellectuals, like Edgell Rickword, were too haunted by the Great War to shoulder the sacrifices again demanded by a failed and discredited government. ${ }^{69}$ John Cornford's observation that "No wars are nice. Even a revolutionary war is ugly enough,"70 reflected the conflicted attitudes many leftists held towards violence, even after Spain. The idealization of Spain, however, allowed the pacifist left redemption and readmission into the anti-Fascist and patriotic mainstream, due to the strengthening of anti-fascist sentiment, and the insistence of the left that the fight would continue on British shores. 


\section{Notes}

${ }^{1}$ Left Review 3, no. 1 (February 1937), 1.

'See Margot Heinemann, "The People's Front and the Intellectuals," in Britain, Fascism and the Popular Front, ed. Jim Fyrth (London: Lawrence and Wishart, 1985), 157-186; Margot Heinemann, "Louis MacNeice, John Cornford and Clive Branson: Three Left Wing Poets," in Culture and Crisis in Britain in the Thirties, eds. Jon Clark, Margot Heinemann, David Margolies, and Carole Snee (London: Lawrence and Wishart, 1979), 103-132; Frederick R. Benson, Writers in Arms: The Literary Impact of the Spanish Civil War (New York: New York University Press, 1967).

${ }^{3}$ Stanley Weintraub, The Last Great Cause: The Intellectuals and the Spanish Civil War (New York: Weybright and Talley, 1968).

${ }^{4}$ Examples include Jim Fryth who focuses on its breadth of the Aid Spain movement in The Signal was Spain: The Spanish Aid Movement in Britain, 1936-39 (London: Lawrence and Wishart, 1986). Others such as Tom Buchanan emphasize the recurrent conflict between mainstream Labour and leftist constituencies both within and without the party in The Spanish Civil War and the British Labour Movement (Cambridge: Cambridge University Press, 1991) and Britain and the Spanish Civil War (Cambridge: Cambridge University Press, 1997).

${ }^{5}$ James K. Hopkins, Into the Heart of the Fire: The British in the Spanish Civil War (Stanford: Stanford University Press, 1998), 4-9.

${ }^{6}$ Robert Stradling, History and Legend: Writing the International Brigades (Cardiff: University of Wales Press, 2003). He argues that the Spanish Republic came to be associated with the defence of "Culture," transforming the military cause into a humanist one, which helped to establish the absolute orthodoxy of the Popular Front. In addition, the Front itself was a complex arena of masculine relationships, both romantic and platonic, between middle-class intellectuals and working-class volunteers.

'Andy Croft, Comrade Heart: The Life of Randall Swingler (Manchester: Manchester University Press, 2003); Croft, ed., A Weapon in the Struggle: The Cultural History of the Communist Party in Britain (London: Pluto Press, 1998); Croft, Red Letter Days: British Fiction in the 1930s (London: Lawrence and Wishart, 1990). See also David Margolies' introduction to Writing the Revolution: Cultural Criticism from 'Left Review' (London: Pluto Press, 1998).

${ }^{8}$ Charles Hobday, Edgell Rickword: A Poet at War (Manchester: Carcanet, 1989), 159.

'See David Margolies, ed., Writing the Revolution; Margot Heinemann "The People's Front and the Intellectuals" and Hanna Behrend, "An Intellectual Irrelevance? Marxist Literary Criticism in the 1930s" in A Weapon in the Struggle, ed. Croft, 106-122.

${ }^{10}$ Left Review 3, no. 5 (June 1935), 364.

${ }^{11}$ Matthew Worley, "Left Turn: A Reassessment of the Communist Party of Great Britain in the Third Period, 1928-33" Twentieth Century British History 2, no. 4 (2000): 353$378,353-4$. Historians with this assessment of the CPGB policy include W. Thompson, F. Beckett, H. Dewar, and K. Laybourn. 
${ }^{12}$ Left Review 2, no. 15 (December 1936), 797.

${ }^{13}$ Stradling, History and Legend, 193-4.

${ }^{14}$ Stephen Spender, World Within World (New York: The Modern Library, [1951] 2001), 222.

${ }^{15}$ Ibid.

${ }^{16}$ See Paul Ward, Red Flag and Union Jack: Englishness, Patriotism and the British Left, 1881-1924 (Suffolk: The Boydell Press, 1998); Hugh Cunningham, "The Language of Patriotism" and Linda Colley, "Radical Patriotism in Eighteenth-Century England," in Patriotism: The Making and Unmaking of British National Identity, ed. Raphael Samuel (London: Routledge, 1989), 57-89, 169-187.

${ }^{17}$ Samuel Hynes, $A$ War Imagined: The First World War and English Culture (London: The Bodley Head, 1990), 449.

${ }^{18}$ Roland N. Stromberg, Redemption by War: The Intellectuals and 1914 (Lawrence, Kansas: The Regents Press of Kansas, 1982), 8, 43.

${ }^{19}$ Hynes, A War Imagined, 464-5.

${ }^{20}$ Martin Ceadel, Pacifism in Britain 1914-1945: The Defining of a Faith (Oxford: Clarendon Press, 1980), 3.

${ }^{21}$ Left Review 1, no. 1 (October 1934), 12.

${ }^{22}$ Ibid., 12, 16.

${ }^{23}$ Left Review 1, no. 2 (November 1934), 13, 47.

${ }^{24}$ Left Review 2, no. 8 (May 1936), 402.

${ }^{25}$ Hopkins, Into the Heart of the Fire, 9-10.

${ }^{26}$ Left Review 3, no. 2, (March 1937).

${ }^{27}$ George Orwell, Homage to Catalonia (Boston: Beacon Hill Press, [1938] 1952), 8-9.

${ }^{28}$ Left Review 3, no. 2 (March 1937), 103.

${ }^{29}$ Valentine Cunningham, "Neutral? 1930s Writers and Taking Sides," in Class, Culture and Social Change: A New View of the 1930s, ed. Frank Gloversmith (Sussex: The Harvester Press, 1980), 45-69.

${ }^{30}$ Criterion (January 1937): 289-90 and Criterion (April 1937): 473.

${ }^{31}$ Left Review 2, no. 13 (October 1936), 671-4.

${ }^{32}$ Left Review 2, no. 15 (December 1936), 794-796.

${ }^{33}$ Left Review 2, no. 16 (January 1937), 857.

${ }^{34}$ Stephen Spender, “Spain Invites the World's Writers," New Writing IV (Autumn 1937).

${ }^{35}$ Spender, World Within World, 261-64.

${ }^{36}$ Left Review 2, no. 13 (October 1936), 681.

${ }^{37}$ Left Review 3, no. 14 (March 1938), 834.

${ }^{38}$ Left Review 3, no. 2 (March 1937), 79-86.

${ }^{39}$ Tom Buchanan, “The Lost Art of Felicia Browne," History Workshop Journal 54 (Autumn 2002): 180-201, 195.

${ }^{40}$ The final issue editorial, Left Review 3 , no. 15 (April 1938): 957-960.

${ }^{41}$ Peter Miles and Malcolm Smith, Cinema, Literature and Society: Elite and Mass Culture in Interwar Britain (Croom Helm: London, 1987), 206. 
${ }^{42}$ Left Review 3, no. 2 (March 1937), 65.

${ }^{43}$ Hynes, $A$ War Imagined, and Modris Eksteins, Rites of Spring: The Great War and the Birth of the Modern Age (New York: Houghton Mifflin, 1989).

${ }^{44} \mathrm{~J}$. M. Winter, Sites of memory, Sites of Mourning: The Great War in European Cultural History (Cambridge: Cambridge University Press, 1995).

${ }^{45}$ Ian MacDougall, ed., Voices from the Spanish Civil War: Personal Recollections of Scottish Volunteers in Republican Spain, 1936-9 (Edinburgh: Polygon, 1986), 140.

${ }^{46}$ Left Review 3, no. 6 (July 1937), 319.

${ }^{47}$ Left Review 3, no. 1 (February 1937), 3.

${ }^{48}$ John Lehmann, T.A. Jackson, and C. Day Lewis, eds., Ralph Fox: Writer In Arms (London: Lawrence and Wishart, 1937), 3-12.

${ }^{49}$ Ibid., 156.

${ }^{\text {so }}$ Ibid., 5, 13-14.

${ }^{51}$ Left Review 1 (June 1935), 391. The article was re-published in Ralph Fox: Writer in Arms, 88-95.

${ }^{52}$ Left Review 1, no. 9 (June 1935), 391.

${ }^{53}$ See Christopher Caudwell and introduction in Scenes and Actions: Unpublished Manscripts, eds. Jean DuParc and David Margolies (London: Routledge \& Keegan Paul, 1986).

${ }^{54}$ Left Review 3, no. 4 (May 1937), 194. Also see Douglas Garman's eulogy for Christopher St. John Sprigg, Left Review 3, no. 6 (July 1937): 352-4.

${ }^{55}$ Weintraub, The Last Great Cause, 39.

${ }^{56}$ Left Review 2 (November 1936). See also Margot Heinemann, "Louis MacNeice, John Cornford and Clive Branson," in Culture and Crisis in Britain in the Thirties, eds. Jon Clark et al., 125.

${ }^{57}$ Stephen Spender, "The Will to Live." Review of John Cornford, A Memoir, ed. Pat Sloan, New Statesman and Nation (12 November 1938).

${ }^{58}$ Philip Toynbee, Friends Apart: A Memoir of Esmond Romilly and Jasper Ridley in the Thirties (London: Sidgwick and Jackson, [1954] 1980).

${ }^{59}$ Benson, Writers in Arms, xix.

${ }^{60}$ Valentine Cunningham, British Writers of the Thirties (Oxford: Oxford University Press, 1988), 431-4.

${ }^{61}$ Left Review 3, no. 2 (March 1937): 75-8. It should be noted that Sommerfield's Memoir of Spain, Volunteer in Spain, was panned by reviewers such as Orwell and T. C. Worsley.

${ }^{62}$ Left Review 3, no. 1 (February 1937), 4.

${ }^{63}$ Mrinalini Sinha illustrates constructing the British colonial masculinity in Colonial Masculinity: 'The 'manly Englishman' and the 'effeminate Bengali' in the late Nineteenth Century (Manchester: Manchester University Press, 1995). See also Graham Dawson, Soldier Heroes: British Adventure, Empire, and the Imagining of Masculinities (London: Routledge, 1994).

${ }^{64}$ British Battalion XV International Brigade: Memorial Souvenir. 
$52 \quad$ Haapamaki

${ }^{65}$ Ibid.

${ }^{66}$ Miles Taylor, "Patriotism, History, and the Left in Twentieth Century Britain," The Historical Journal 33 (1990): 971-987, 982.

${ }^{67}$ Stephen Lutman, "Orwell's Patriotism," Journal of Contemporary History 2 (1967);

149-58.

${ }^{68}$ Ibid., 317.

${ }^{69}$ Hobday, Edgell Rickword, 216-8.

${ }^{70}$ John Cornford: A Memoir, ed. Pat Sloan (London: Jonathan Cape, 1938), 242. 